\title{
Successive changes in distribution patterns as an adaptive strategy in the bivalve Macoma balthica (L.) in the Wadden Sea
}

\author{
J. J. Beukema \\ Netherlands Institute for Sea Research; P. O. Box 59, 1790 AB Den Burg, Texel, \\ The Netherlands
}

\begin{abstract}
During their first year in the Wadden Sea, high proportions of the tidal-flat populations of the tellinid bivalve Macoma balthica (L.) redistribute twice: immediately after their settlement in late spring, the postlarvae show a net transportation in a shoreward direction - whereas in the subsequent winter, the grown spat move in the reverse direction. As a consequence of these two periods of high mobility, distribution patterns shift twice: though initial settlement takes place mainly in the lower half of the intertidal, most spat grow to a size of $\sim 0.5 \mathrm{~cm}$ in the upper half of it, whereas most adults live in the middle and lower zones. The successive distribution patterns of spat and older Macoma are described in detail for Balgzand, an extensive tidal-flat area in the westernmost part of the Wadden Sea. Long-term observations in this area and published evidence from other areas are used to evaluate the suitability of different tidal zones as a habitat for successive life stages of Macoma. For spat, the upper zone is a more favourable habitat than the lower, because predation pressure (mainly from shrimp) and disturbance are less and growth is more rapid. For adults, the upper parts are no longer a favourable habitat, because the few animals that stay suffer from high parasite load, low survival, slow growth and low reproductive output. It is concluded that in their successive life stages the majority of $M$. balthica live at the intertidal level most favourable to them. The strategy of timely shifts to areas more suitable to the next life stage contributes to the success of the species: it is the most widespread and common (and one of the most stable) macrozoobenthic species in the Wadden Sea.
\end{abstract}

\section{INTRODUCTION}

In many animal species, young life stages demand an environment that is different from that of the adults. Juvenile habitats are often more specialized Hence, their distribution is more restricted than that of adults. In particular, the need for spatial refuges from predation is more acute in the more vulnerable (smaller) juveniles (Wahle \& Steneck, 1992, and examples therein). On tidal flats, predation pressure on juvenile macrofauna is heavier in the lower than in higher parts (Reise, 1983, 1985). In several macrobenthic species of the tidal flats of the Wadden Sea, the highest densities of juveniles are indeed found in the higher parts of the tidal flats; the less vulnerable adults of the same species are common over a wider depth range, and more abundant in lower parts, than the juveniles. This is so, for example, in the lugworm Arenicola marina (Farke et al., 1979, Dankers \& Beukema, 1983), the shore crab Carcinus maenas (Klein Breteler, 1976). the brown shrimp Crangon crangon (Janssen \& Kuipers, 1980; Beukema, 1992a) and the bivalve Macoma balthica (Beukema et al,, 1978; Dankers \& Beukema, 1983). 
M. balthica (L.) is one of the most successful species of the Wadden Sea. It occurs at relatively high densities (tens or hundreds per $\mathrm{m}^{2}$ ) on nearly all tidal flats (Beukema, 1976; Dankers \& Beukema, 1983) and in subtidal areas (Dekker, 1989). In macrozoobenthos samples from the Wadden Sea, it is the most common species - both in the intertidal (Beukema, 1976) and in the subtidal (Dekker, 1989). Areas of high abundance include a wide range of sediment types and depths (Dankers \& Beukema, 1983). However, not all age groups are to be found at high densities in all coastal areas. Initial settlement of postlarvae in spring (at a size of $<0.5 \mathrm{~mm}$ ) takes place mainly in the lower half of the intertidal (Armonies \& Hellwig-Armonies, 1992). A few months later, the juveniles (with a shell length between 0.1 and $1 \mathrm{~cm}$ ) occur in maximal numbers on the higher tidal flats, around or above mean tide level (MTL) (Dankers \& Beukema, 1983; Armonies \& HellwigArmonies, 1992). However, animals of 1 year or older (mostly sized between 1 and $2.5 \mathrm{~cm}$ ) are more evenly distributed over all types of tidal flat and the shallow subtidal (compare the two parts of Fig. 20 of Dankers \& Beukema, 1983).

The differential distribution of the successive age groups of $M$. balthica poses questions on both causative mechanisms and functional aspects. The accumulation of juveniles (spat) on high (coastal) tidal flats appears to be caused by the passive settlement of pelagic postlarvae on the sediment in quiet areas (but mostly at low intertidal levels) combined with high mobility in the earliest bottom stages, resulting in net shoreward moves to areas with higher intertidal levels (Ratcliffe et al., 1981; Günther, 1991; Armonies \& Hellwig-Armonies, 1992). The more even and widespread distribution of adults appears to be largely a result of subsequent offshore movements of juveniles during a second period of high mobility in their first winter (Fig. 1). During winter, numerical densities of juvenile Macoma rapidly decline on high (coastal) tidal flats, which at the same time increase on low (offshore) tidal flats (Wolff \& de Wolf, 1977; Beukema et al., 1978) and in the subtidal (Kleef \& Essink, 1982; Beukema \& de Vlas, 1989). During winter, juveniles with a shell length between about 2 and $8 \mathrm{~mm}$ are found in high numbers in the water, particularly at ebb tide (Beukema \& de Vlas, 1989). This off-shore winter migration involves active behavioural components: as a response to lowered ambient temperatures they leave the sediment and protrude their foot (Sörlin, 1988). In moving water, they form long mucous threads. This significantly promotes their drag and thereby their chance to be carried away by currents. Their suspended stay in the water column is also lengthened (Beukema \& de Vlas, 1989), and consequently the distance covered before sinking again to the bottom. By thread drifting, young bottom stages (up to a size of about $9 \mathrm{~mm}$ ) of Macoma are transported by tidal currents over distances up to some tens of $\mathrm{km}$ (Beukema \& de Vlas, 1989). As many more are present in the water at ebb rather than at flood tides, the net transport in winter is in an offshore direction, resulting in a shift to lower intertidal and even subtidal levels.

Such migratory behaviour must be adaptive: it cannot have evolved without a function. The main question addressed in the present paper is: how do tidal zones differ in their suitability as a habitat for the successive life stages of $M$. balthica? In other words: what are the advantages, to the youngest (first-summer) bottom stages, of concentrating in the higher parts of the tidal flats and what are the disadvantages of staying there as adults?

An extensive data set is available from regular sampling of bottom fauna of Balgzand, a tidal-flat area in the Wadden Sea. The 15 sampling stations cover various types of 


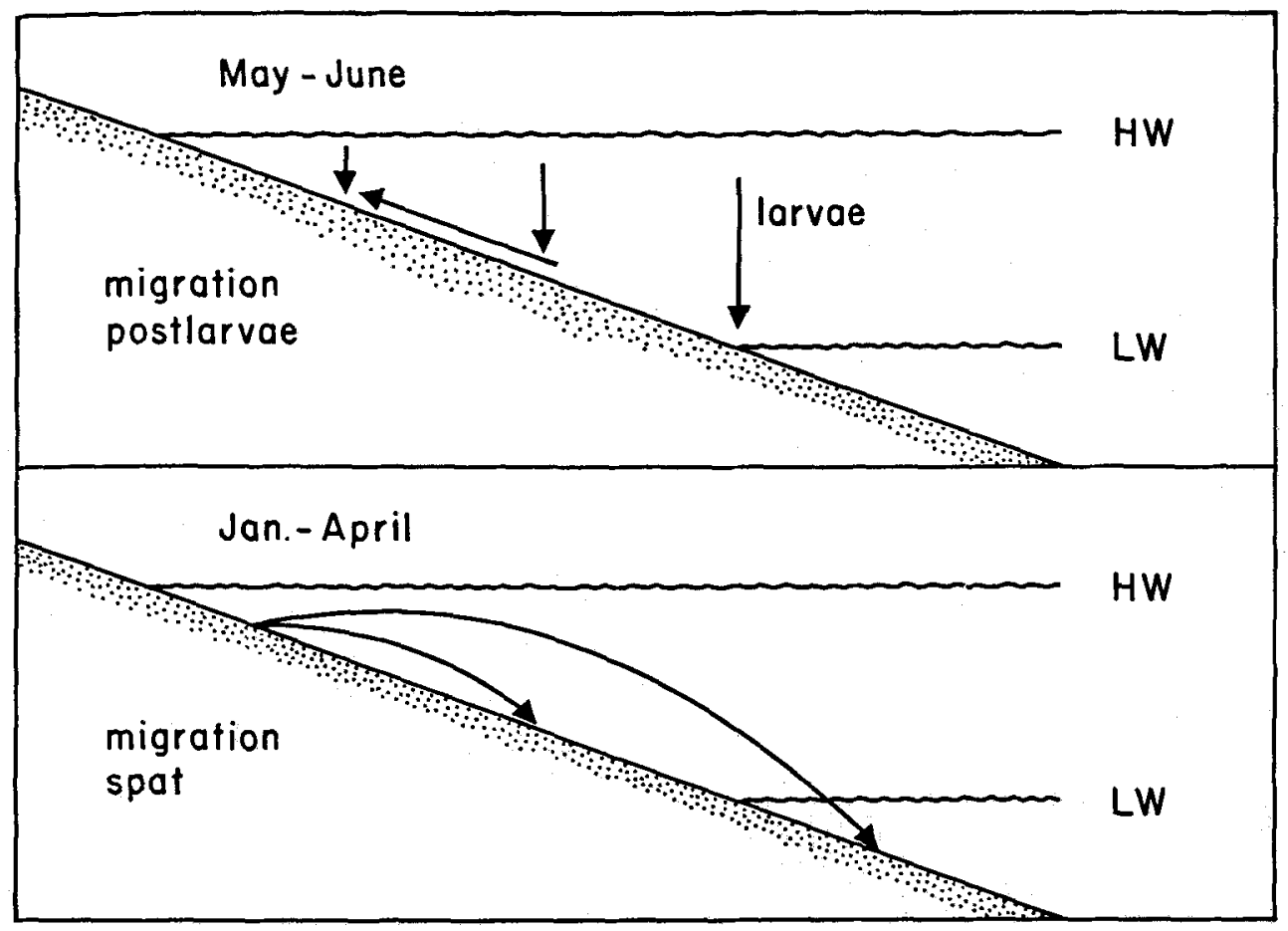

Fig. 1. A diagram of the two successive migrations shown by the mass of the young benthic stages of Macoma balthica: (top) shoreward migration of the very small newly-settled postlarvae immediately after settlement in late spring, and (bottom) offshore migration of $\sim 0.5$-cm long spat in winter, after a stay of about 7 to 10 months at high tidal flats

sediment and the entire intertidal range. Data on numerical densities of the age classes of Macoma can be used for detailed comparison of distribution patterns of juveniles and adults, and to study changes in distribution patterns of cohorts. Moreover, rates of both survival and growth in different areas can be calculated and compared to see whether stayers or movers are at an advantage. The same sampling programme provides data on environmental conditions in the various areas, including abundance estimates of interacting species. Such data can help explain local differences in survival and growth of $M$. balthica and thus define the optimal habitats for its successive life stages.

\section{MATERIAL AND METHODS}

Detailed data on distribution patterns of Macoma balthica are available from a longterm sampling programme (started around 1970) of the macrozoobenthos at 15 permanent stations ( 12 transects of $1 \mathrm{~km}$ each and 3 squares of $900 \mathrm{~m}^{2}$ each) on Balgzand, a 50 . $\mathrm{km}^{2}$ tidal-flat area in the westem-most part of the Wadden Sea (Fig. 2). These stations cover the entire intertidal depth range (Fig. 3), which runs on average from about +60 to about $-77 \mathrm{~cm}$, compared to MTL or +54 to -83 with respect to Dutch Ordinance Level (DOL). DOL is used in the following as 0 -level. In some cases, data obtained at transects-2 


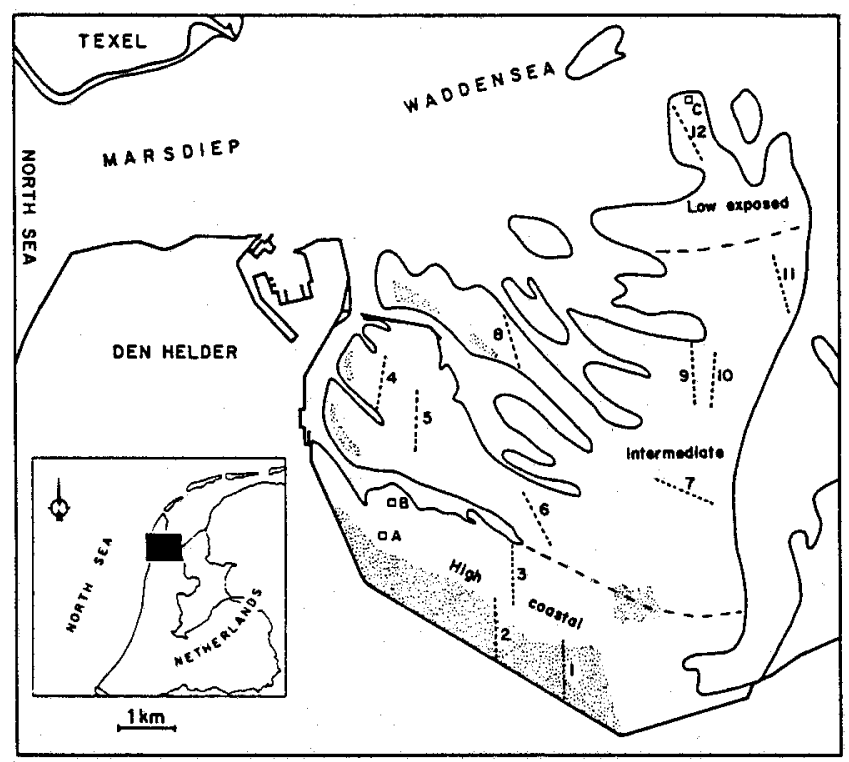

Fig. 2. The Balgzand tidal-flat area, i.e. the area above mean low-water level, roughly indicated by the thin line. The positions of the 15 sampling stations ( 3 squares: $A, B$ and $C$, and the 12 transects: numbered 1 to 12 ) are indicated

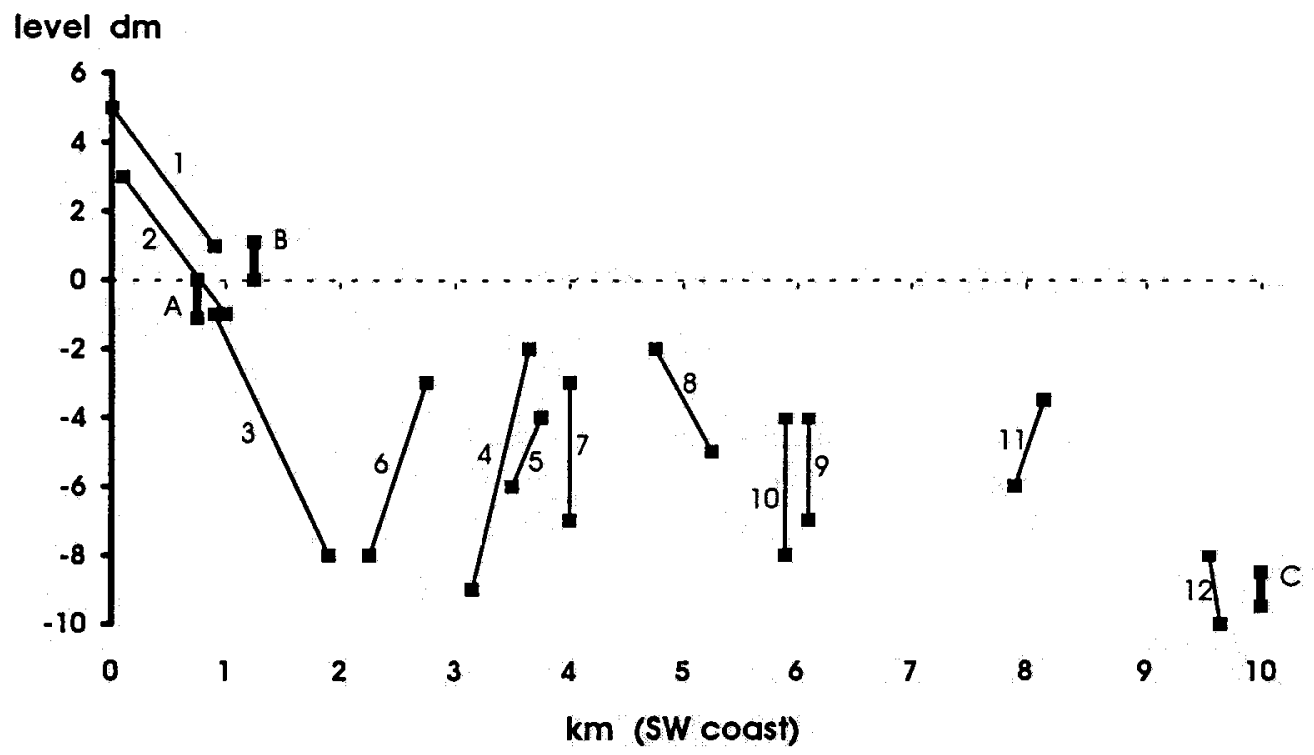

Fig. 3. The 15 sampling stations (see Fig. 2) arranged according to distance from the SW coast (in km, horizontal axis) and intertidal level (dm + or - DOL, which is close to MTL, see Fig. 4a). Note that transects- 2 and -3 together cover nearly the entire intertidal range within about 0.1 and almost $2 \mathrm{~km}$ from the coast without much overlap (depicted in detail in Fig. 4a) 
and -3 will be dealt with separately, because together these two neighbouring transects cover nearly the entire intertidal depth range (from almost +4 to nearly $-9 \mathrm{dm}$; see Fig. 4a). For comparison, the same data are shown for the remaining 13 stations (and not for the complete set of 15 stations) to obtain two independent data sets. These stations cover an even wider depth range: from +5 to $-10 \mathrm{dm}$.

Since 1973, the stations have been sampled annually in a uniform way, both in late winter (mostly in March) and in late summer (mostly in August). In the present paper, only the summer data are used. Sampling procedures have been described in detail in earlier papers (e. g. Beukema, 1974). In short: cores were taken and sieved in the field on 1-mm mesh screens, thus retaining only those Macoma with a shell length of over 1.5 to $2 \mathrm{~mm}$.

Along the transects 50 sediment cores were taken at equal intervals $(20 \mathrm{~m})$, but 5 successive cores were lumped together in a sample representing a 100-m stretch. Each of these $100-\mathrm{m}$ samples covered $0.045 \mathrm{~m}^{2}$. Within the squares, 9 or 16 cores were taken. Altogether, there were 125 samples of 5 cores each, which were allotted to 16 depth classes $(+5$ to $-10 \mathrm{dm})$. In the following, all numerical densities are expressed in $\mathrm{n} . \mathrm{m}^{-2}$ and are usually averages of 19 estimates (viz. the 19 years 1973-1991). Survival is estimated from changes in numerical densities of the same (groups of) year classes. It is expressed as $z\left(=\ln n_{1} / n_{0}\right)$.

In the laboratory, the samples were sorted. Macoma was sorted to age class, according to the number of winter marks on the shell. This can be done accurately up to an age of about 5 years (Lammens, 1967). Thus, density data are available for 5 successive age classes for 125 sampling stations. Averages are shown for 0-group (spat), 1-group and all older animals together (2+-group).

After lumping together the samples from each transect or square, all individuals of each of the age classes distinguished were measured to the nearest $\mathrm{mm}$. The soft parts were removed from the shells and dried and ashed per $\mathrm{mm}$ group (shell length $\mathrm{L}$ in $\mathrm{mm}$ ). In this way, data were obtained for ash-free dry weight (AFDW, W in $\mathrm{mg}$ ) for 15 stations and 19 years. A condition factor (CF) was calculated from W.L- ${ }^{3}$. Summer data were used for CF of animals of the $2+$-group.

Annual growth rates were estimated from increments in shell length during their second season of growth. The raw data obtained were corrected, to compensate for differences in initial length, according to Beukema et al. (1977). The corrected length increment $\left(\mathrm{LIN}_{c}\right)$ is expressed in $\mathrm{mm}$ and represents the average annual increase in shell length of an animal exactly $6 \mathrm{~mm}$ long at the start of the growing season.

Statistical methods applied included the $t$-test (if the distribution of the data was approximately normal) or, in other cases, non-parametric tests such as the Spearman rank correlation test (to evaluate trends) and the Wilcoxon or Mann-Whitney U-test (to evaluate differences in level).

\section{RESULTS}

\section{Differential distribution patterns of successive age groups}

\section{0 -group Macoma}

In late summer (August) the numbers of spat were invariably higher in the samples from the upper half of the intertidal than in the samples from the lower intertidal. The zone of 

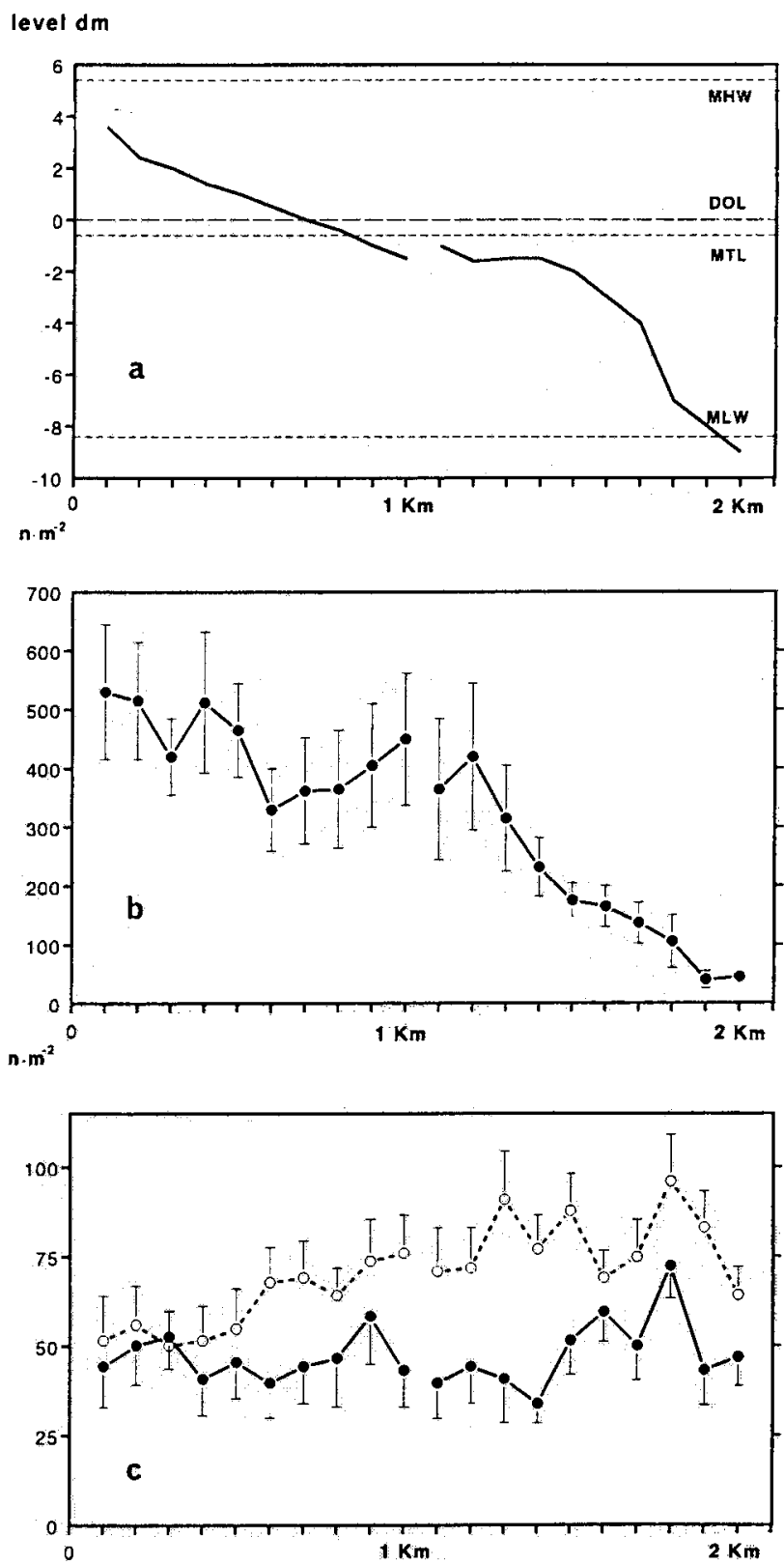

Fig. 4. at The intertidal levels (in $\mathrm{dm}$ with respect to DOL) of the successive $100-\mathrm{m}$ stretches of transects 2 and -3 (see Fig. 2). Broken lines indicate mean high water (MHW), mean low water (MLW), mean tide level (MTL), and Dutch Ordinance level (DOL). The latter is used as the 0 -level. Data from sounding surveys by the former Studiedienst Hoorn of Rijkswaterstaat, $b$. Mean densities (n. ${ }^{-2}$ averages of 19 years, with 1 standard error) of Macoma spat observed in August at the successive $100-\mathrm{m}$ stretches of transects -2 and -3 , c. The same as b for 1 -year-old Macoma (solid points, solid line) and of 2 - or more year-olds (open points, broken line) 
generally high densities of spat included all of transect- 2 and the coastal part of transect3 (Fig. 4 b), i. e. the range of intertidal levels between about +3 and $-2 \mathrm{dm}$ (compare Fig. 4a). At more offshore locations, spat densities rapidly declined with the increasing depth. Along these two transects, the mean spat densities were positively correlated with intertidal level (Spearman's $\mathrm{r}=+0.87, \mathrm{p}<0.001$ ). In the upper half of the combined transect- $2+3$, spat densities were roughly an order of magnitude higher than at the 100-m stretches close to mean low-water level (MLW). The standard errors shown in Fig. $4 \mathrm{~b}$ clearly show that such differences were highly significant statistically.

The data from the other sampling stations (10 transects plus the 3 squares) corroborate the general distribution patterns of high densities of spat in a zone above and around MTL, and low densities at lower intertidal levels ( $-3 \mathrm{dm}$ and lower, Fig. 5a). Below and around MLW ( -8 to $-10 \mathrm{dm}$ ), spat densities were even two orders of magnitude lower than above and around MTL. The standard errors included in Figure 5a show such differences to be highly significant. Around mean high-water level (MHW) (samples taken at about $+5 \mathrm{dm}$ ), spat densities were also relatively low. Thus the samples taken along this full intertidal depth range showed maximal densities of spat at a restricted intertidal depth range, extending from about $+4 \mathrm{dm}$ down to about $-2 \mathrm{dm}$ (i.e. the higher half of the intertidal zone), where densities were on average above 500 per $\mathrm{m}^{2}$.

The densities shown in Figure 5a are 19-year averages. Over most of the intertidal range, they are dominated by the 5-year data with a higher-than-average recruitment (450 to 1300 spat per $\mathrm{m}^{2}$ ), whereas the data from the remaining 14 years, with only $\sim 100$ to $\sim 300$ spat per $\mathrm{m}^{2}$, play a minor role. The distribution patterns of spat in these two groups of years were clearly different. In each of the 5 years having a successful recruitment, high densities of spat $\left(>500 \mathrm{~m}^{-2}\right)$ were observed in a broad zone extending from +3 to $-5 \mathrm{dm}$ (Fig. $5 \mathrm{~b}$ ). In the other 14 years, the zone of high densities of spat was much narrower, and densities of $>500 . \mathrm{m}^{-2}$ were restricted to relatively high intertidal levels: +4 to $+2 \mathrm{dm}$. At all intertidal levels below $+2 \mathrm{dm}$, spat densities were significantly $(\mathrm{p}<0.01)$ higher in the group of the 5 successful years than in the other years. Above this level, however, these differences were all non-significant $(p>0.05)$. Thus in "poor" years, numbers of spat were reduced at all levels lower than about $+2.5 \mathrm{dm}$ (Fig. $5 \mathrm{~b}$ ). In a tidal-flat area in the eastern part of the Dutch Wadden Sea. Zwarts (1988, Fig. 4.26) observed a similar phenomenon.

\section{1- and 2+-group Macoma}

The densities of older Macoma along transects -2 and -3 showed a pattern that clearly differed from that of the spat. Both in the 1-year-old and in the $2+$ age groups, the numbers were almost equal at all distances from the coast (Fig. 4c), i.e. at all levels from about +3 to about $-8 \mathrm{dm}$. If there was any relationship with level, such a relationship for adults was the reverse of that for spat (compare Figs $4 \mathrm{~b}$ and $4 \mathrm{c}$ ). The negative correlation with intertidal level was statistically significant in the $2+$-group only $(r=-0.73, p<0.01)$ and not in the 1 group. Nevertheless, the distribution pattern of the 1-group resembled that of the $2+$ group rather than that of the spat (compare Fig. $4 \mathrm{~b}$ and the two lines in Fig. 4c).

The data from the other stations, with a complete intertidal depth range, corroborate the similarity of the distribution patterns of 1- and 2+-group Macoma. The two groups were abundant at a broad depth range, extending from +3 to $-7 \mathrm{dm}$ (Fig. $5 \mathrm{c}$ ). Densities were lower at the extreme levels, both near the high-water (HW) mark $(+4$ and $+5 \mathrm{dm})$ 

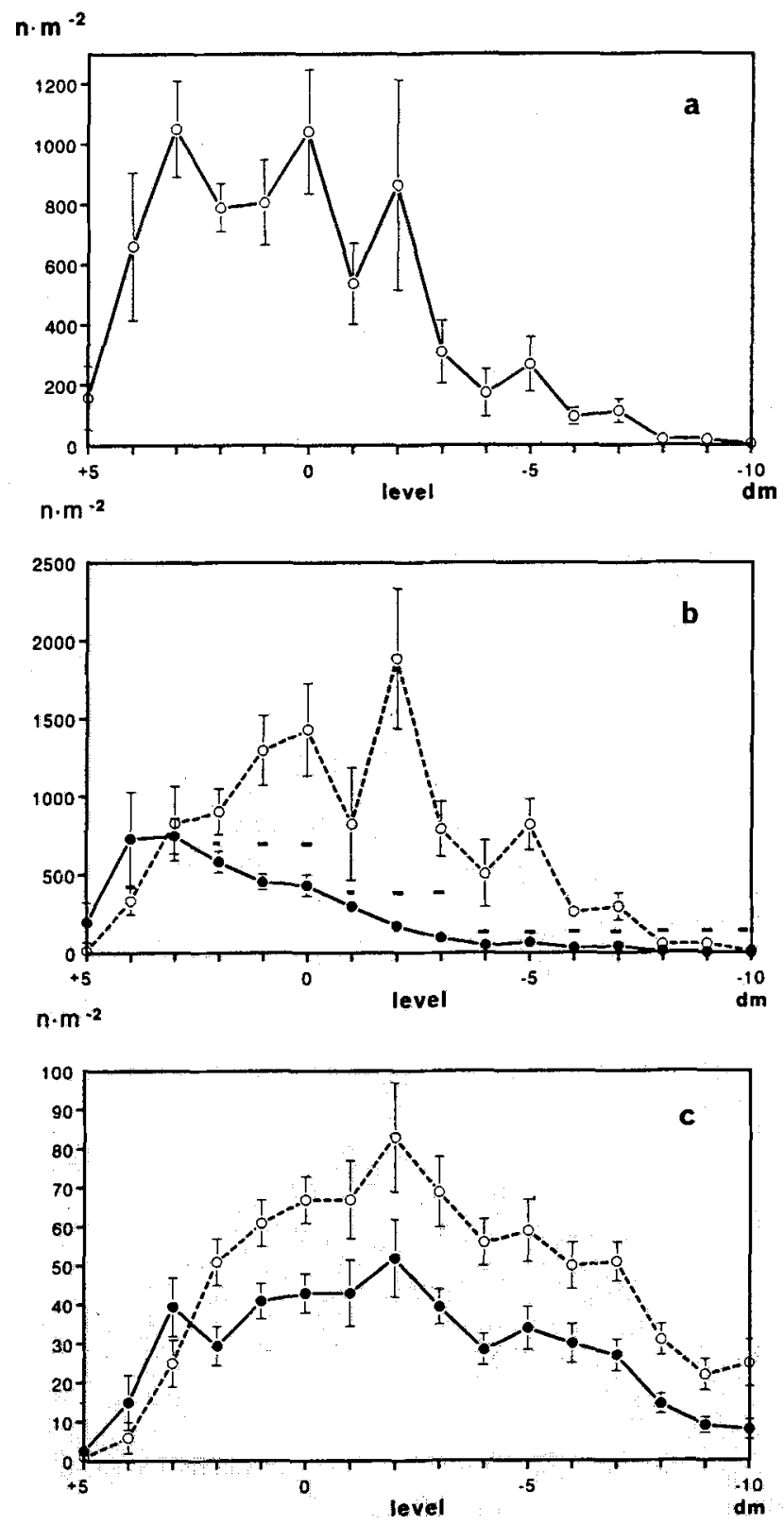

Fig. 5. Mean numbers of Macoma per $\mathrm{m}^{2}$ (with 1 standard error) observed in summer at 16 intertidal levels (horizontal axis, in dm), on Balgzand, of a: 0-group in all 19 years (1973-1991); b: 0-group separately for 5 years with above-average densities (broken line) and the other 14 years with belowaverage densities (solid line) (levels of significance of the differences between the means of the two data sets are indicated by small bold bars (-) for p<0.01, c: 1-group Macoma (solid points, solid line) and 2+-group Macoma (open points, broken line) in all 19 years, Data from 105 annual samples (100-m stretches of all stations except transects- 2 and -3) 
and near the low-water (LW) mark. The very high levels of +4 and $+5 \mathrm{dm}$ were not covered by transect- 2 (compare Fig. 4). Compared to the distribution patterns observed along transect-3 (Fig. 4c), the densities of 1- and 2+-group Macoma were relatively low near the LW mark $(-8$ to $-10 \mathrm{dm})$ in the other Balgzand areas (Fig. $5 \mathrm{c}$ ). These areas are generally sandier and more exposed (to strong currents by tides and wind) than the relatively sheltered near-coastal area of transects-2 and -3 . The patterns shown in Figure $5 \mathrm{c}$ are more widely applicable for Macoma distribution than those of Figure $4 \mathrm{c}$.

\section{Differences between the distribution of 0-group and older Macoma}

Distribution patterns of 1 - and 2+-group Macoma were similar (see above), but differed from those of spat, particularly at the lower intertidal levels. The older age groups remained relatively abundant down to -7 or $-8 \mathrm{dm}$ (Figs $4 \mathrm{c}$ and $5 \mathrm{c}$ ), whereas high densities of spat did not usually extend below $-2 \mathrm{dm}$ or (in successful years) $-5 \mathrm{dm}$ (Fig. 5b).

The difference between the successive distribution patterns of spat (as shown in Figs $4 b ; 5 a, b$ ) and older age groups (see Figs $4 c, 5 c$ ) can be expressed quantitatively as a "survival" ratio, viz. as the quotient of number of 1 -year-olds found in year- 1 divided by the number of spat in year- 0 at the same place. Fig. 6 shows such ratios separately for the

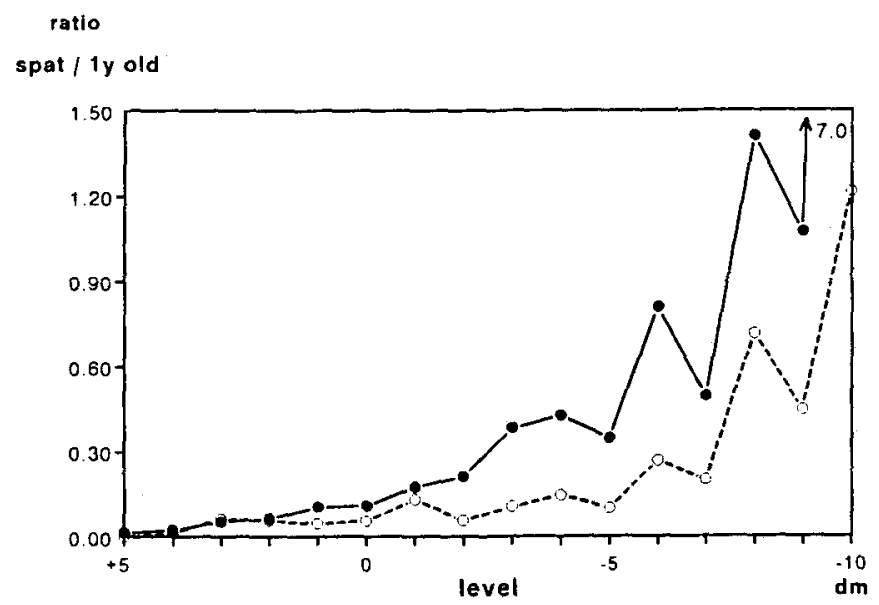

Fig. 6. Ratio of numbers of 1-year-old Macoma divided by numbers of spat observed 1 year earlier at the same intertidal level (horizontal axis, in dm). Summed data are used from 1973-1991 (spat) and 1974-1992 (1-year-olds), separately for the 5 strong year classes (broken line) and the 14 weak year classes (solid line)

data of the 5 strong year classes (born in 1979, 1984, 1985, 1987, and 1991) and for the other 14 year classes of the 1973-1991 period. The lower the level of the sampling place, the higher this ratio was for both data sets ( $p<0.001$ and $p<0.001$, Spearman test). Near MI.W, some ratios were even above 1.0, indicating increasing densities. Immigration apparently overruled mortality at these low intertidal levels. 


\section{Differential mortality at various intertidal levels}

Reliable estimates of mortality during the first year of life of Macoma cannot be derived from density changes at any place, because young benthic stages show mass movements both during their first summer (Armonies, 1992) and during their first winter (Beukema \& de Vlas, 1989). After their first-winter migration, however, the then 1-yearold animals appeared to stay in (almost) the same place. Observations (own, unpublished) of repopulation rates of depopulated areas clearly show that 1+ Macoma rarely migrate over distances of more than about $1 \mathrm{~m}$. Thus, genuine mortality rates during the second and following years can be estimated from changes in local density.

Annual mortality rates were calculated as $\mathrm{z}$ values for all 15 sampling stations and for all 19 years (1973-1991) for $1+$ as compared to $2+$ numbers one year later. Average annual mortality rates were higher in high than in low intertidal ares (Fig. $7: r=+0.68$,

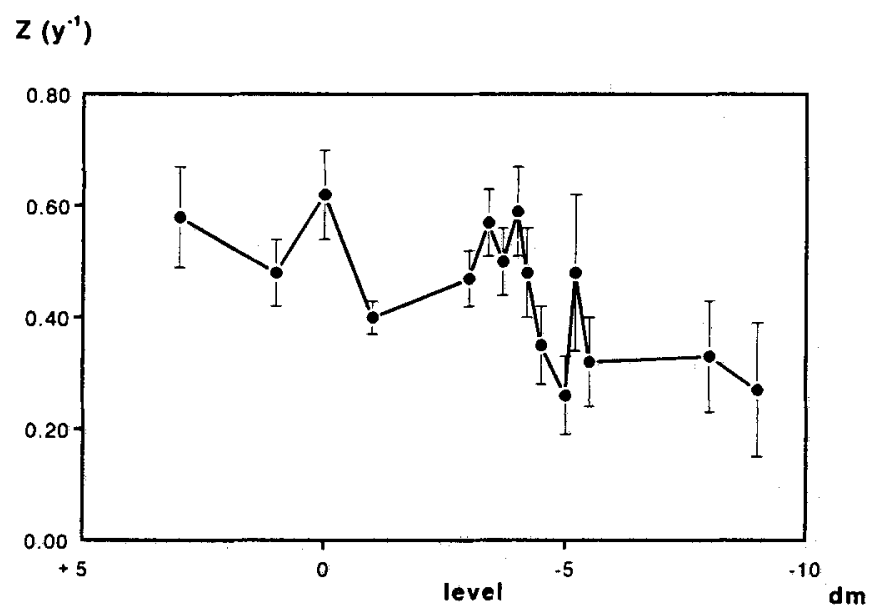

Fig. 7. Mean annual mortality $\left(z\right.$, in $\left.\mathrm{a}^{-1}\right)$ of adult Macoma at the 15 stations, arranged according to their mean intertidal level (horizontal axis, in dm): 19-year averages 1973-1991 (with one standard error)

$\mathrm{p}<0.02, \mathrm{n}=15$, Spearman test). The consequence of the correlation between lower annual mortality and increasing depth can be seen in Figs $4 \mathrm{c}$ and $5 \mathrm{c}$ : with increasing depth, the numbers of old $(2+)$ animals became gradually higher than those of the 1 year-olds.

\section{Differential growth at various intertidal levels}

Precise growth rates are difficult to assess in spat, again because of the high proportions that migrate. Moreover ${ }_{t}$ as only data from $1-\mathrm{mm}$ sieves are available, I refrain from presenting data on growth rates of Macoma of spat size.

Thus, only estimates of growth during a later growing season (in this case the second one) will be presented. Length increase during the second season of growth was generally less above than below MTL (Fig. 8a) Inspection of the standard errors reveals that growth rates at the two highest stations were significantly lower than those at all 

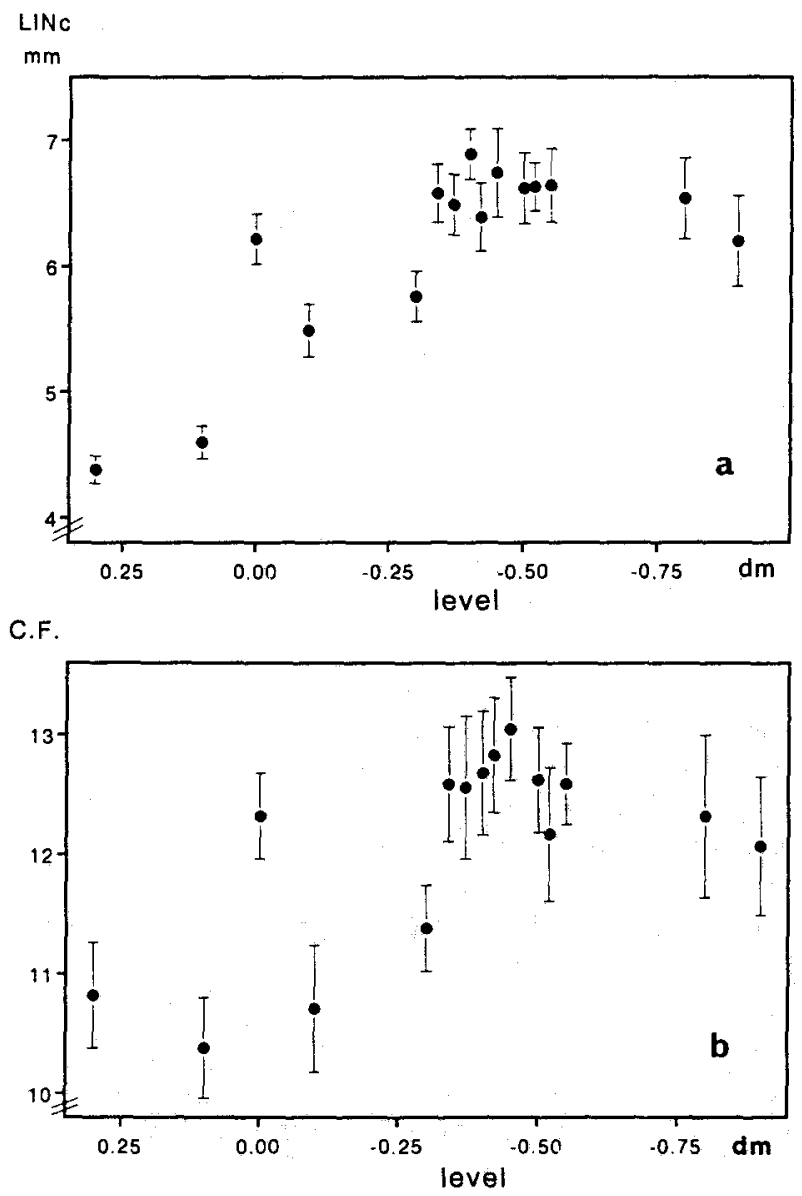

Fig. 8. Relationships between intertidal level (horizontal axis, in $\mathrm{dm}$ ) and (a) mean standardized growth in length during the second season of growth (LINc in $\mathrm{mm}$ ) and (b) mean condition factor CF of adult Macoma (in mg AFDW per $\mathrm{cm}^{3}$ ). Each of the 15 figures represents 1 station; 12-year (1980-1991) averages with 1 standard error

other stations. The declining trend with increasing level was also significant $(\mathrm{r}=-0.60$, $\mathrm{p}<0.05, \mathrm{n}=15$ ).

Condition factors in August showed the same trend with intertidal level (Fig. 8b), but the trend was hardly significant $(r=-0.52, p-0.05, n=15)$. As expected from the above two correlations, growth expressed in weight units also increased from high to low intertidal levels. As weight changes with roughly the third power of length, differences in weight increase were more spectacular than those expressed in length units. At the highest stations, mean growth rates in weight units were only about half of those observed in the lower half of the intertidal (viz. about 12 vs $24 \mathrm{mg}$ AFDW during the second season of growth). 


\section{DISCUSSION}

\section{First-summer Macoma}

According to Günther (1991) and Armonies \& Hellwig-Armonies (1992), the distribution pattern of Macoma spat in the Wadden Sea in summer and autumn is a result of initial larval settlement (mainly May-June), taking place mostly in the lower intertidal, followed by a net shoreward transportation to higher intertidal areas, where postlarval densities continue to increase after settlement. Ratcliffe et al. (1981) observed a similar shoreward shift, during summer, in the Humber estuary. Postlarvae remain highly mobile during the first weeks (maybe even months) after the first settlement. It appears unlikely that they are transported directly to higher areas. Most probably, there is a process of settlement and re-suspension several times in succession at various levels, during the course of which settlement grows more permanent at the upper levels. From this viewpoint, postlarvae do not show a real migration, but rather experience passive transportation(s) by tidal currents, the net result being a shoreward shift in the distribution pattern. Anyhow, in the second half of the year, maximal spat densities are observed at the upper tidal flats. This distribution pattern of more or less full-grown spat has been observed not only at Balgzand (Figs 4b, 5b), but also in other parts of the Dutch, German and Danish Wadden Sea (Thamdrup, 1935; Obert, 1982; Wilkens et al., 1983; Zwarts, 1988) and elsewhere (the former Grevelingen estuary: Wolff \& de Wolf, 1977; the Wash: Reading, 1979).

The following environmental factors would affect Macoma spat differently at high versus low intertidal flats:

Physical stress. In most of the Wadden Sea, low tidal flats are situated farther away from the shore than high flats. Accordingly, the low flats are generally more exposed to wave action and tidal currents than the higher flats. In the more exposed Wadden Sea areas, the early postlarvae of Macoma are hardly bigger than a mediumsized sand grain (150-200 $\mathrm{um}$ ). Normal life-functions would hardly be possible for small Macoma (which have to live in the uppermost sediment layer) if surrounding sand grains of such a size were moving by currents from wave-action and tides. Such areas appear to be more suitable as a habitat for adults - which can live in deeper sediment layers because of their longer siphons. Initial spatfall appears to be low on exposed coarsegrained sediments (Armonies \& Hellwig-Armonies, 1992) and the settled postlarvae will either be passively moved or stimulated by the water movement to leave the sediment (cf. Sörlin, 1988). They will subsequently be transported by tidal currents (with the help of long threads) to other quieter areas with finer sediments.

Biological disturbance. Results of experiments by Ratcliffe et al. (1981) indicate that adult Macoma make their spat more vulnerable to movements by water currents, though the exact mechanism is unknown. It might just be a loosening of the sediment surface structure. Sediment structure is mainly changed by re-working activities of the lugworm Arenicola marina (Cadée, 1976). Field experiments involving manipulation of lugworm abundance showed that the presence of lugworms in densities of about 30 or more per $\mathrm{m}^{2}$ has a significantly negative effect on the abundance of Macoma of spat size (Flach, 1992). Such high densities of adult lugworms hardly ever occur above MTL, but are frequent at tidal flats below this level (Figs 3 and 4 of Beukema 
\& de Vlas, 1979). The highest densities of adult Macoma also occur at elevations below MTL (Fig. 5c).

Growing conditions. Armonies \& Hellwig-Armonies (1992) observed a more rapid increase in mean length of Macoma spat at their upper, than at their lower, sampling stations. Though changes in mean size may not reflect real growth rates (because high proportions of the animals migrate), in this case the possible bias would probably work in the opposite direction (small animals migrating in an upward direction). It is therefore justified to conclude that growth rates in spat are higher at high than at low intertidal levels. Observations on Balgzand (Dekker, pers. comm.) corroborate this view.

Predation pressure. During the main settlement period of Macoma (May in the Wadden Sea), the most important predator on small tidalflat benthos appears to be the shrimp Crangon crangon. Densities of small shrimp on the tidal flats have rapidly reached high levels by May already, particularly after mild winters (Beukema, 1992a). Keus (1986) observed Macoma spat of $\sim 1 \mathrm{~mm}$ length in the stomachs of small $(1-2 \mathrm{~cm})$ shrimps on Balgzand. He found individual shrimp to eat such quantities of spat that the former would generally be able to drastically reduce the abundance of Macoma spat. However, neither in all years nor at all intertidal levels would shrimp densities be high enough for such a reduction in spat numbers. At the highest tidal flats $(+3 \mathrm{dm}$ or higher), shrimps were hardly ever found. At levels around MTL ( +2 to $-3 \mathrm{dm})$, nearly all those observed were small $(<2 \mathrm{~cm})$ and their biomass values on the whole rather low. Higher biomass values were generally observed in the lower half of the intertidal (Fig. 9), where larger shrimps were also present, particularly in areas imperfectly drained at low tide. This distribution pattern of shrimp would mean that Macoma spat always find a refuge

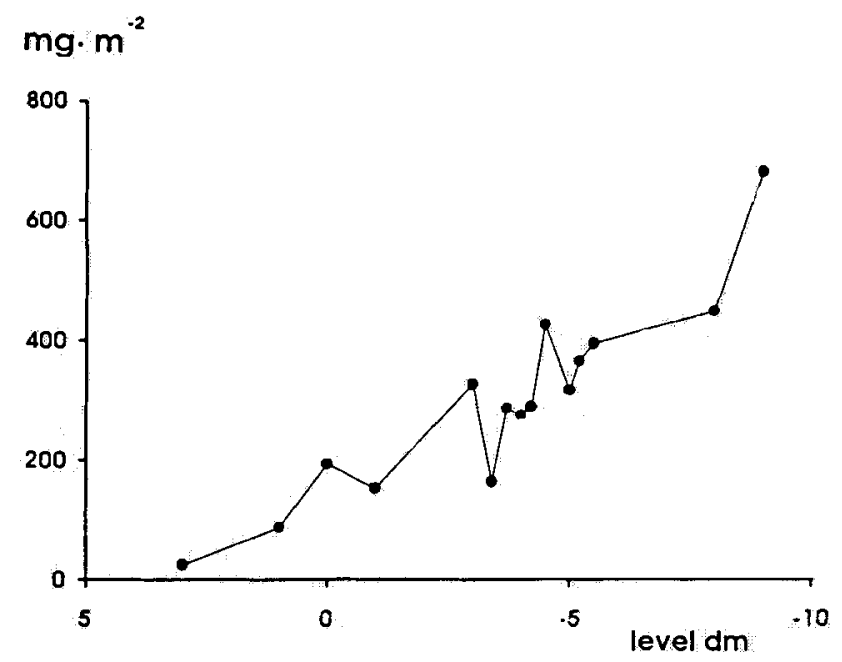

Fig, 9. Shrimp (Crangon crangon) biomass (in $\mathrm{mg}^{-2}$ ) at different intertidal levels (in dm with respect to DOL). Each of the 15 points represents one sampling station (see Fig 2) Average biomass values calculated from mean numbers observed over 14 years $(1979-1992)$ in August and (less frequently collected) data on length-distribution of shrimps at each station 
from shrimp predation at the highest tidal flats (at about $+2 \mathrm{dm}$ and higher). They would also be relatively safe at levels around MTL in years with low shrimp abundance.

The data on spat abundance in late summer corroborate this view. Spat densities were invariably high (several hundreds per $\mathrm{m}^{2}$ ) at levels between +4 and $+2 \mathrm{dm}$ and nearly always low (some tens or less per $\mathrm{m}^{2}$ ) at levels below $-7 \mathrm{dm}$ (Fig. 5b). At intermediate levels, spat densities were only high in exceptional years (broken line in Fig. 5b). Detailed data on shrimp abundance are available for only 11 years (cf. Beukema, 1992a). They do indeed point to relatively low shrimp abundance in years with high spat densities. Mean shrimp biomass in the last decade of Mays (probably the most important settlement period for Macoma) amounted to $63 \pm 14 \mathrm{mg} \cdot \mathrm{m}^{-2}$ in the 5 years having high spat densities in a broad intertidal range, and to $147 \pm 25 \mathrm{mg} \cdot \mathrm{m}^{-2}$ in the 6 years where the more frequent pattern of high spat densities was restricted to high intertidal levels (no detailed shrimp data are available for the 8 other years included in Fig. 5). Thus, Macoma spat appears to be able to survive at intermediate intertidal levels only in years with low shrimp abundance. In most years, however, only the highest zone appears to be a safe area for Macoma spat. The generally observed distribution pattern of spat in late summer (solid line of Fig. 5b: high densities restricted to a narrow high zone) thus appears to be a net results of both tidal-current transportation (which may be undirected) and a low survival of postlarvae settling at lower elevations.

\section{Older Macoma}

In their first winter, Macoma redistribute by thread-drifting (Sörlin, 1988; Beukema \& de Vlas, 1989). This winter migration of spat is clearly separated from the postlarval summer move by a long autumn period without thread-drifting activity (Beukema \& de Vlas, 1989). The new distribution pattern established during late winter remains permanent. After the winter migration, the distribution in the intertidal is more even than before, the average distance from the coast has increased, and the average intertidal level has lowered accordingly (compare Fig. $4 \mathrm{~b}$ with $4 \mathrm{c}$, and Fig. $5 \mathrm{a}$ with $5 \mathrm{c}$ ). Similar shifts of Macoma distribution patterns between the age of 0 and 1 year have been observed by Reading (1979) in the Wash, and can be derived from data presented for the Danish Wadden Sea by Thamdrup (1935, Table 13). Only low proportions of the originally high numbers of spat at the higher intertidal levels remained there (Fig. 6). At the lower extreme of the intertidal depth range, the populations near MLW must have originated almost completely from the immigration of full-grown spat in winter (as is the case with subtidal areas: Beukema \& de Vlas, 1989).

For the few Macoma remaining at the highest intertidal levels, the habitat (so favourable for them during their first summer) ist no longer optimal, Lower intertidal areas appear to be a better habitat for adult Macoma in the following respects:

Mortality. Mean annual survival of adults was higher at low than at high intertidal levels (Fig. 7). The cause of this difference is unknown, but predation by wader birds might play a role, as the time available for their feeding is longer at high than at low intertidal levels. Another cause might be the higher proportions of adult Macoma bearing parasites at high, than at low, levels (Hulscher, 1973, Swennen \& Ching, 1974; Lim \& Green, 1991). Parasitized Macoma appear to suffer high mortality (Hulscher, 1973). Another cause of enhanced mortality might be the occasional exposure for over-lonq 
periods to sub-lethal temperatures on hot days. Such high temperatures $\left(>30^{\circ} \mathrm{C}\right)$ will occur more frequently and for longer periods on high than on low tidal flats. Macoma of spat size are more tolerant of such conditions than larger ones (Ratcliffe et al., 1981).

Growth and condition. Both mean annual growth rates and condition factors at the end of the growing season were higher at low than at high intertidal levels (Fig. 8). In the St. Lawrence estuary, Harvey \& Vincent $(1989,1991)$ also observed more rapid growth at lower elevations, but Green (1973) and Bachelet (1980) found the reverse relationship in the Hudson Bay and the Gironde estuary, respectively. Local conditions and way of feeding appear to be important. For suspension feeders, lower levels would mean longer immersion times and thus longer daily feeding periods. Suspension-feeding bivalves generally grow more rapidly at low elevations (Peterson \& Black, 1988). Though from a morphological point of view Macoma are deposit feeders, they are also able to filtrate the overlying water. Depending on the type of habitat, they behave primarily as either deposit or suspension feeders (Olafsson, 1986). In the Balgzand area, adult Macoma appear to obtain most of their food from the overlying water and not from the sediment surface (Hummel, 1985; Kamermans, 1992).

Reproduction. In the St. Lawrence estuary, Harvey \& Vincent (1989) observed that Macoma living at lower intertidal levels produce more gametes than those living at higher levels. Gamete production in this area is largely assured by the small populations living low in the intertidal.

The Summary (Table 1) of the most suitable habitats for spat and adult Macoma shows that for roughly the same factors (growth, and some factors affecting survival) the upper intertidal provide better conditions for spat, whereas the lower intertidal is more favourable for adults. Thus, Macoma of the two life stages generally live in the habitat that is most favourable to them. They reach it by timely migration, the net result of which is in the optimal direction: shoreward immediately after larval settlement and offshore after having reached a length of $\sim 0.5 \mathrm{~cm}$. The two mass moves are thus clearly functional: they belong to an adaptive strategy.

Several more species of bivalves are able to migrate by thread drifting (examples are mentioned in Beukema \& de Vlas, 1989), but so far the possible functions of this ability

Table 1. Summary of differential optimal levels $(H=$ higher half and $L=$ lower half of the intertidal) for various life-history aspects of spat (first summer of life) and adult (more than 1-year-old) Macoma

\begin{tabular}{|c|c|c|}
\hline & Spat & Adults \\
\hline Growth & H 2,3 & L 1,$7 ;$ H 8,9 \\
\hline Condition & & L 1 \\
\hline Survival & & L 1 \\
\hline Predation & $\mathrm{H} 1$ & \\
\hline Disturbance & $\mathrm{H} 4$ & \\
\hline Parasites & & L 5 \\
\hline Reproduction & - & L 6 \\
\hline \multicolumn{3}{|c|}{$\begin{array}{l}\text { References: 1: this paper; 2: Armonies \& Hellwig-Armonies (1992); 3: Dekker (pers. comm.); } \\
\text { 4: Flach (1992); 5: Swennen \& Ching (1974), Lim \& Green (1991), Hulscher (1973); 6: Harvey \& } \\
\text { Vincent (1989); 7: Harvey \& Vincent (1991); 8: Green (1973); 9: Bachelet (1980) }\end{array}$} \\
\hline
\end{tabular}


have hardly been investigated. These species might provide additional examples of migrations to avoid unfavourable conditions for certain life stages, thus adjusting distribution patterns of successive life stages to their specific demands. In the Wadden Sea, the intricate life history of the lugworm Arenicola marina, as described by Farke et al. (1979) and Reise (1985), would be another example.

Apparently, the newly-settled postlarvae of Macoma migrate shoreward primarily to avoid the high predation pressure on small animals that is so prevalent in the lower intertidal (Reise, 1983, 1985). The more severe physical and biological disturbance and the lower growth rates in the lower zone would render them more vulnerable to predators specialized in small prey (such as the extraordinarily dense populations of juvenile shrimps, shore crabs and fishes). As Reise (1985) rightly remarks, predation appears to be the most important biological interaction and the most important structuring force on tidal flats. Predatory pressure, then, may have been the driving force in the evolution of the well-developed migratory abilities in newly-settled Macoma.

Once the spat has grown up within the refuge in the upper intertidal, they have to move back to lower and more offshore areas. Individuals staying in the upper zone would soon experience difficulties with their energy balance, as judged from the low growth rates and reproductive outputs (cf. Harvey \& Vincent, 1989). If high numbers stayed in the upper zone, the situation would become even worse by negative density effects, as Vincent et al. (1989) observed - particularly in the upper parts of the intertidal zone. Other disadvantages of staying in the upper zone would include more infestation by parasites, a higher loss to wading birds, and occasional exposure to lethally high temperatures.

In conclusion: the successive mass moves of Macoma, which ensure that the successive life stages reach the most suitable intertidal level in time, contribute to the success of the species in the Wadden Sea. All different types of habitats within the Wadden Sea are easily reached by the spat migrating in winter over long distances with the help of long mucous threads (Sörlin, 1988; Beukema \& de Vlas; 1989). Thus a re-population takes place every year in areas where younger life stages could not generally survive in any number due to the heavy predation pressure exerted by numerous epibenthic predators (shrimps, shore crabs, fishes), particularly in the lower parts of the intertidal and in the subtidal. This may explain why Macoma balthica is the most common macrozoobenthic species of the Wadden Sea. The wide distribution of the older stages further adds to the stability of the species by diffusing the risks of specific dangers which would operate fully in only some of the many habitats inhabited.

$M$. balthica is also a relatively stable species compared to the other, often violently fluctuating, bivalves in the Wadden Sea (Beukema et al., 1983). The use of a refuge by juveniles effectively prevents the complete recruitment failures in certain years so frequently observed in other bivalve species in the Wadden Sea (Beukema, 1992b). Thus, the first (shoreward, summer) move appears mainly to serve recruitment stability, whereas the second (downward, winter) migration primarily ensures the spread of the populations over a wide variety of habitats. 


\section{LITERATURE CITED}

Armonies, W., 1992. Migratory rhythms of drifting juvenile molluscs in tidal waters of the Wadden Sea. - Mar. Ecol. Prog. Ser. 83, 197-206.

Armonies, W. \& Hellwig-Armonies, M., 1992. Passive settlement of Macoma balthica spat on tidal flats of the Wadden Sea and subsequent migration of juveniles. - Neth. J. Sea Res. 29, 371-378.

Bachelet, G., 1980. Growth and recruitment of the tellinid bivalve Macoma balthica at the southern limit of its geographical distribution, the Gironde estuary (SW France). - Mar. Biol. 59, 105-117.

Beukema, J. J., 1974. Seasonal changes in the biomass of the macrobenthos of a tidal flat area in the Dutch Wadden Sea. - Neth. J. Sea Res. 8, 94-107.

Beukema, J. J., 1976. Biomass and species richness of the macro-benthic animals living on the tidal flats of the Dutch Wadden Sea. - Neth. J. Sea Res. 10, 236-261.

Beukema, J. J., 1992a. Dynamics of juvenile shrimp Crangon crangon in a tidal-flat nursery of the Wadden Sea after mild and cold winters. - Mar. Ecol. Prog. Ser. 83, 157-165.

Beukema, J. J., 1992b. Expected changes in the Wadden Sea benthos in a warmer world: lessons from periods with mild winters. - Neth. J. Sea Res. 30, 73-79.

Beukema, J. J. \& de Vlas, J., 1979. Population parameters of the lugworm, Arenicola marina, living on tidal flats in the Dutch Wadden Sea. - Neth. J. Sea Res. 13, 331-353.

Beukema, J. J. \& de Vlas, J., 1989. Tidal-current transport of thread-drifting postlarval juveniles of the bivalve Macoma balthica from the Wadden Sea to the North Sea. - Mar. Ecol. Prog. Ser. 52, 193-200.

Beukema, J. J., Cadée, G. C. \& Jansen, J. J. M., 1977. Variability of growth rate of Macoma balthica (L.) in the Wadden Sea in relation to availability of food. In: Biology of benthic organisms. Ed. by B. F. Keegan, P. O. Ceidigh \& P. J. S. Boaden. Pergamon Press, Oxford, 69-77.

Beukema, J. J., de Bruin, W. \& Jansen, J. J. M., 1978. Biomass and species richness of the macrobenthic animals living on the tidal flats of the Dutch Wadden Sea: long-term changes during a period with mild winters. - Neth. J. Sea Res. 12, 58-77.

Beukema, J. J., Cadée, G. C. \& Hummel, H., 1983. Differential variability in time and space of numbers in suspension and deposit feeding benthic species in a tidal flat area. - Oceanologica Acta 1983, (Vol. spéc.) 21-26.

Cadée, G. C., 1976. Sediment reworking by Arenicola marina on tidal flats in the Dutch Wadden Sea. - Neth. J. Sea Res. 10, 440-460.

Dankers, N. \& Beukema, J. J., 1983. Distributional patterns of macrozoobentic species in relation to some environmental factors. In: Ecology of the Wadden Sea. Ed. by W. J. Wolff. Balkema, Rotterdam, 1 (4), 69-103.

Dekker, R., 1989. The macrozoobenthos of the subtidal western Dutch Wadden Sea. I. Biomass and species richness. - Neth. J. Sea Res. 23, 57-68.

Farke, H., Wilde, P. A. W. J. de \& Berghuis, E. M., 1979. Distribution of juvenile and adult Arenicola marina on a tidal mud flat and the importance of nearshore areas for recruitment. - Neth. J. Sea Res. 13, 354-361.

Flach, E. C., 1992. Disturbance of benthic infauna by sediment-reworking activities of the lugworm Arenicola marina. - Neth. J. Sea Res. 30, 81-89.

Green, R. H., 1973. Growth and mortality in an arctic population of Macoma balthica (Pelecypoda, Tellinidae), - J. Fish. Res. Bd Can. 30, 1345-1348.

Günther, C.-P., 1991. Settlement of Macoma balthica on an intertidal sandflat in the Wadden Sea. Mar. Ecol. Prog. Ser. 76, 73-79.

Harvey, M. \& Vincent, B., 1989. Spatial and temporal variations of the reproductive cycle and energy allocation of the bivalve Macoma balthica (L.) on a tidal flat. - J. exp. mar. Biol. Ecol. 129, 199-217.

Harvey, M. \& Vincent, B., 1991. Spatial variability of length-specific production in shell, somatic tissue and sexual products of Macoma balthica in the Lower St. Lawrence Estuary. I. Small- and meso-scale variability. - Mar. Ecol. Prog. Ser. 75, 55-66.

Hulscher, J. B., 1973. Burying-depth and trematode infection in Macoma balthica - Neth. J. Sea Res. $6,141-156$.

Hummel, H., 1985. Food intake of Macoma balthica (Mollusca) in relation to seasonal changes in its potential food on a tidal flat in the Dutch Wadden Sea - Neth. J. Sea Res, 19, 52-76. 
Janssen, G. M. \& Kuipers, B. R., 1980. On tidal migration in the shrimp Crangon crangon. - Neth. J. Sea Res. 14, 339-348.

Kamermans, P., 1992. Similarity in food source and timing of feeding in deposit- and suspensionfeeding bivalves. In: Growth limitation in intertidal bivalves of the Dutch Wadden Sea. Thesis, State Univ. Groningen, 59-82.

Keus, B., 1986. De predatie van de garnaal (Crangon crangon) op het broed van het nonnetje (Macoma balthica). - NIOZ - Rapp. 1986-5, 1-43.

Kleef, H. L. \& Essink, K., 1982. Onderzoek naar redistributie van Macoma balthica broed in het voorjaar in de Bocht van Watum (Eems-Dollard estuarium). - Rapp. Rijksinst. Zuiv. Afvalwater Groningen $B J-M V$ 82-03, 1-3.

Klein Breteler, W. C. M., 1976. Settlement, growth and production of the shore crab, Carcinus maenas, on tidal flats in the Dutch Wadden Sea. - Neth. J. Sea Res. 10, 354-376.

Lammens, J. J., 1967. Growth and reproduction in a tidal flat population of Macoma balthica (L.) Neth. J. Sea Res, 3, 315-382.

Lim, S. S. L. \& Green, R. H., 1991. The relationship between parasite load, crawling behaviour, and growth rate of Macoma balthica (L.) (Mollusca, Pelecypoda) from Hudson Bay, Canada. - Can. J. Zool. 69, 2202-2208.

Obert, B., 1982. Bodenfauna der Watten und Strände um Borkum-Emsmündung. - Jber. ForschSt. Insel-Küstenschutz, Norderney 33, 139-162.

Ólafsson, E. B., 1986. Density dependence in suspension-feeding and deposit-feeding populations of the bivalve Macoma balthica: a field experiment. - J. Anim. Ecol. 55, 517-526.

Peterson, C. H. \& Black, R. 1988. Responses of growth to elevation fail to explain vertical zonation of suspension-feeding bivalves on a tidal flat. - Oecologia 76, 423-429.

Ratcliffe, P. J., Jones, N. V. \& Walters, N. J., 1981. The survival of Macoma balthica (L.) in mobile sediments. In: Feeding and survival strategies of estuarine organisms. Ed. by N. V. Jones \& W. J. Wolff. Plenum Press, New York, 91-108.

Reading, C. J., 1979. Changes in the downshore distribution of Macoma balthica (L.) in relation to shell length. - Estuar. coast. mar. Sci. 8, 1-13.

Reise, K., 1983. The role of predation on intertidal flats. In: Ecology of the Wadden Sea. Ed. by W. J. Wolff. Balkema, Rotterdam, 1 (4), 104-107.

Reise, K., 1985. Tidal flat ecology. Springer Berlin, $191 \mathrm{pp}$.

Sörlin, T., 1988. Floating behaviour in the tellinid bivalve Macoma balthica (L.). - Oecologia 77, $273-277$.

Swennen, C. \& Ching, H. L., 1974. Observations on the trematode Parvatrema affinis, causative agent of crawling tracks of Macoma balthica. - Neth. J. Sea Res. 8, 108-115.

Thamdrup, H. M., 1935. Beiträge zur Ökologie der Wattenfauna auf experimenteller Grundlage. Meddr Kommn Danm. Fisk-og Havunders. (Ser. Fiskeri) 10 (2), 3-125.

Vincent, B., Joly, D. \& Brassard, C., 1989. Effets de la densité sur la croissance du bivalve Macoma balthica (L.) en zone intertidale. - J. exp. mar. Biol. Ecol. 126, 145-162.

Wahle, R. A. \& Steneck, R. S., 1992. Habitat restrictions in early benthic life: experiments on habitat selection and in-situ predation with the American lobster. - J. exp. mar. Biol. Ecol. 157, 91-114.

Wilkens, H., Andres, H.-G., Faubel, A., Gillandt, L., Hartwig, E., Hüppop, O., Martens, J. M. \& Schulz, K., 1983. Ökologische Analyse der Leybucht. - Arb. ForschSt. Norderney 8, 1-144.

Wolff, W. J. \& de Wolf, L., 1977. Biomass and production of zoobenthos in the Grevelingen Estuary, the Netherlands. - Estuar. coast. mar. Sci. 5, 1-24.

Zwarts, L., 1988. De bodemfauna van de Fries-Groningse waddenkust. - Flevober. Rijksdienst IJsselmeerpolders, Lelystad 294, 1-195. 